\title{
SENSITIVITY OF MEDITERRANEAN BIVALVE MOLLUSC AQUACULTURE TO CLIMATE CHANGE, OCEAN ACIDIFICATION, AND OTHER ENVIRONMENTAL PRESSURES: FINDINGS FROM A PRODUCER SURVEY
}

\author{
LUÍS C. RODRIGUES, ${ }^{1,2 *}$ JEROEN C. J. M. VAN DEN BERGH,${ }^{1,3,4 \dagger}$ FABIO MASSA, ${ }^{5}$ \\ JOHN A. THEODOROU, ${ }^{6,7}$ PATRIZIA ZIVERI ${ }^{1,3}$ AND FRÉDÉRIC GAZEAU ${ }^{8,9}$ \\ ${ }^{1}$ Institute of Environmental Science and Technology, Edifici Z, Campus UAB, Universitat Autònoma de \\ Barcelona, 08193 Bellaterra, Spain; ${ }^{2}$ ENT Environment and Management, c/ Sant Joan 39, primer pis, 08800 \\ Vilanova i la Geltrú, Barcelona, Spain; ${ }^{3}$ ICREA, Passeig Lluís Companys 23, 08010 Barcelona, Spain; \\ ${ }^{4}$ Faculty of Economics and Business Administration, and Institute for Environmental Studies, VU University \\ Amsterdam, De Boelelaan 1105, 1081 HV Amsterdam; ${ }^{5}$ General Fisheries Commission for the Mediterranean \\ $(G F C M)$, Fisheries and Aquaculture Department, Food and Agriculture Organization of the United Nations \\ (FAO), Viale delle Terme di Caracalla 00153, Rome, Italy; ${ }^{6}$ Department of Fisheries and Aquaculture \\ Technology, Technological Educational Institution (T. E. I.) of Western Greece, Nea Ktiria Gr 30200, \\ Mesolonghi, Greece; ${ }^{7}$ Department of Agricultural Economics, Faculty of Bioscience Engineering, University of \\ Gent, Coupure Links 653, B-9000 Gent, Belgium; ${ }^{8}$ Sorbonne Universités, UPMC University, Paris 06, UMR \\ 7093, LOV, Observatoire océanologique, F-06230, Villefranche/mer, France, ${ }^{9} \mathrm{CNRS}$, UMR 7093, LOV, \\ Observatoire océanologique, F-06230, Villefranche/mer, France
}

\begin{abstract}
Human-induced climate change and ocean acidification are global environmental phenomena with a common driver: anthropogenic emissions of carbon dioxide. Both processes potentially threaten the Mediterranean bivalve mollusc aquaculture sector, which is economically relevant to several regions and countries. Detrimental effects on bivalve mollusc species might arise from the associated increase in sea surface temperature, $\mathrm{pH}$ reduction, higher frequency of extreme climatic events, and possible synergies with other nonclimatic stressors, such as harmful algal blooms and mollusc diseases. This paper presents the results of a questionnaire-based study of Mediterranean bivalve mollusc producers from 12 coastal regions and six countries, the latter including those with the highest production share in the Mediterranean region. This study aims to assess knowledge and perception of threat of climatic and nonclimatic environmental stressors within the Mediterranean aquaculture industry. Furthermore, it collects information about the (geographical) impacts of summer heat waves and ocean acidification. The results suggest that ocean acidification is still a relatively unknown phenomenon and generally poorly understood. Moreover, it is considered a secondary threat compared with other pressures. Summer heat waves are presently perceived as the highest threat, having been observed in a majority of the studied production sites in past years, with effects on seed (spat), adult mortality, and byssus attachment.
\end{abstract}

KEY WORDS: climate change, sea warming, ocean acidification, Mediterranean Sea, aquaculture, bivalve molluscs

\section{INTRODUCTION}

Climate change and ocean acidification are global environmental threats with a common cause: anthropogenic emissions of carbon dioxide $\left(\mathrm{CO}_{2}\right)$ (IPCC 2013). The increase of this greenhouse gas in the atmosphere and its feedback on the climate causes global temperature rise in the lower atmosphere and ocean. The surface ocean has warmed between 1971 and 2010 by $0.11^{\circ} \mathrm{C}$ per decade (IPCC 2013), whereas the highest temperature increase have been recorded in the coastal zone, namely $0.18^{\circ} \mathrm{C}$ (Lima \& Wethey 2012). Depending on the future emission scenario, surface ocean temperatures are projected to warm in the top $100 \mathrm{~m}$ by about $0.6-2.0^{\circ} \mathrm{C}$ by 2100 (IPCC 2013). Nearly $50 \%$ of the emitted anthropogenic $\mathrm{CO}_{2}$ accumulates in the atmosphere. Oceans are the largest natural reservoirs of carbon and are responsible for $26 \%$ of $\mathrm{CO}_{2}$ uptake (average for 2003 to 2012) (Le Quéré et al. 2014). The accumulation of $\mathrm{CO}_{2}$ in seawater leads to an increase of its acidity level (i.e., a decrease in seawater $\mathrm{pH}$ ). An increase of $26 \%$ in acidity (i.e., a $\mathrm{pH}$ decrease from 8.2 to 8.1 ) has been estimated during the last two centuries

*Corresponding author. E-mail: luis.rodrigues@uab.es $\dagger$ Fellow of Tinbergen Institute.

DOI: $10.2983 / 035.034 .0341$
(IPCC 2013). An additional pH decrease between 0.06 and 0.32 is projected for the end of the $21^{\text {st }}$ century, depending on the considered emission scenario (IPCC 2013).

Climate projections under a business-as-usual scenario for the Mediterranean area indicate a potential increase in sea surface temperature (SST) of $1-1.5^{\circ} \mathrm{C}$ in the Eastern Mediterranean, Aegean, and Adriatic Sea from 2000 to 2050, with summer SST regularly surpassing $29^{\circ} \mathrm{C}$ in the South Eastern Mediterranean (Lovato et al. 2013). In the Northwestern Mediterranean Sea, mean maximum summer SST has increased by about $1{ }^{\circ} \mathrm{C}$ between 2002 and 2010 relative to 1980 to 2000 (Macias et al. 2013), whereas a rapid warming is projected for the end of the century (Gualdi et al. 2013 and references therein). Recent work has demonstrated that ocean acidification in the Northwest Mediterranean Sea is already detectable, with a decrease of $0.0013 \mathrm{pH}$ unit per year between 1998 to 2000 and 2003 to 2005 (Meier et al. 2014), close to the rates observed in other areas of the global ocean (Orr 2011). Furthermore, a 30\% increase in acidification between 2010 and 2050 may be expected, implying a $60 \%$ increase in ocean acidity because of the industrial revolution (Ziveri \& MedSeA Consortium 2014).

The potential impact of ocean warming on marine organisms has been studied for decades. Among many consequences, 
the increase in seawater temperature has been shown to be responsible for, inter alia, mass mortality events (e.g., Coma et al. 2009), increased sensitivities to pathogens (e.g., Harvell et al. 2002), species invasions (e.g., Stachowicz et al. 2002), and phenological shifts (e.g., Edwards \& Richardson 2004). The interest of the scientific community in the effects of ocean acidification on marine organisms is of a more recent date (The Royal Society 2005), and its impact in the Mediterranean basin has only received closer attention in the current decade (Ziveri 2012). Most of the research effort has focused on organisms producing calcium carbonate skeletons or shells (Kroeker et al. 2014 and references therein). Indeed, whereas decreasing $\mathrm{pH}$ levels are expected to have profound impacts on the physiology and metabolism of marine organisms through a disruption of intercellular transport mechanisms (Pörtner et al. 2004), the seawater $\mathrm{pH}$ decrease will also lead to a decrease in the concentration of carbonate ions $\left(\mathrm{CO}_{3}{ }^{2-}\right)$, one of the building blocks of calcium carbonate $\left(\mathrm{CaCO}_{3}\right)$, and likely alter the ability of calcifying organisms to precipitate $\mathrm{CaCO}_{3}$ (Gazeau et al. 2007, Kroeker et al. 2014, Meier et al. 2014).

Among vulnerable species to climate change and ocean acidification are bivalve molluscs, such as mussels, oysters, and clams [For the purpose of simplification, the term "molluscs" will be used to in the rest of the paper, even though this group includes non-shelled species such as cephalopds (FAO 2010).]. In the Mediterranean Sea, in the coming decades, these species will most likely experience increased thermal stress due to unusually high SST. Anestis et al. (2007) have shown that the Mediterranean mussel Mytilus galloprovincialis already lives in summer and in certain regions of the Mediterranean Sea near or beyond its upper critical temperature $\left(25-28^{\circ} \mathrm{C}\right)$. This suggests a potential vulnerability of these species to extreme climatic events such as summer heat waves, and to a more gradual tendency of sea warming expected with climate change. Under high SST, several effects may occur in different life stages of the species (larvae, seed or spat, juvenile, and adult), inter alia, decrease in survival rate, slower growth, and inability for the species to develop their organic protective layers (Gazeau et al. 2014). The latter study shows that adult mussels are highly sensitive to warming with $100 \%$ mortality observed at increased temperature $\left(+3^{\circ} \mathrm{C}\right)$ in summer. Other potential effects arising from climate change on mollusc may comprise habitat changes and physical disturbance as a result of sea level rise or higher frequency of storms affecting wind and wave conditions. More extreme fluctuations in precipitation leading to episodes of floods or droughts could influence the flow and concentration of nutrients and pollutants in estuarine and coastal areas, on occasions, contributing to the depletion of oxygen (hypoxia and anoxia) (Callaway et al. 2012).

Regarding ocean acidification, the decrease in seawater $\mathrm{pH}$ levels and diminished availability of carbonate minerals could hamper the development of early life stages of molluscs, the process of calcification, growth, byssus attachment, and survival (e.g., Kroeker et al. 2013, Gazeau et al. 2013, O’Donnell et al. 2013). Experiments show that at $\mathrm{pH}$ levels of 0.4 units lower than current ones (namely 7.7 instead of 8.1), certain mollusc species start experiencing some of the previous effects (see comprehensive review from Gazeau et al. 2013). Several experiments have focused on the combined impacts of ocean acidification and warming, with contrasting results (antagonistic, additive, or synergistic) (e.g., Lannig et al. 2010, Hiebenthal et al. 2013, Duarte et al. 2014, Kroeker et al. 2014, Mackenzie et al. 2014). In the Mediterranean Sea, few experiments have focused on the effects of ocean acidification alone (Michaelidis et al. 2005, Bressan et al. 2014, Gazeau et al. 2014, Range et al. 2014) and only one focused on the combined effects of warming and acidification (Gazeau et al. 2014). This latter study showed that growth is potentially affected by ocean acidification only in summer when the organisms face suboptimal conditions, a result that is consistent with field observations near natural $\mathrm{CO}_{2}$ vents (Rodolfo-Metalpa et al. 2011). Although requiring further research, warming and acidification could enhance other harmful stressors of mollusc species. Examples include the dispersal of pathogenic organisms and harmful algal blooms (HAB), potentially detrimental to human health (e.g., shellfish poisoning) (Cochrane et al. 2009, Rosa et al. 2012).

In 2010, capture and aquaculture of molluscs represented $\sim 10 \%$ of world seafood production (FAO 2010). From a total of 18 million tonnes produced in the world, $81 \%$ came from mariculture, i.e., combining aquaculture production in marine and brackish water environments, $2 \%$ from freshwater aquaculture, and the remaining 17\% from capture fisheries (wild fisheries) (FAO 2010). Despite its relatively low significance at the world level ( $\sim 1 \%$ of total production), Mediterranean mollusc mariculture is economically relevant to some regions and countries. This activity is developed in 14 of the 22 national territories bordering the Mediterranean Sea, in a diverse set of environments (e.g., lagoons, coasts/bays, offshore areas), and employing various techniques (e.g., production in trays, stakes, ropes suspended from rafts, and long lines) (Danioux et al. 2000). Italy, Greece and France appear as the three top producers, whereas the native species Mediterranean mussel Mytilus galloprovincialis is the main cultivated species (FAO 2010).

Some production sites, often located near river estuaries and areas where agriculture is practiced, already suffer from associated pressures of eutrophication and hypoxia, which can act in synergy with climate change and ocean acidification. This has been documented for the Ebro delta (Spain), Etang de Thau (France), Venice Lagoon and Gulf of Trieste (Italy), Thermaikos Gulf (Greece), and Lake Bizerte (Tunisia) (WRI 2014, Rosa et al. 2012). Negative implications of climatic and nonclimatic pressures affecting both the mollusc sector and the associated local economies and societies comprise diverse issues. These might include: production losses due to mollusc mortality episodes; damage to physical capital as an outcome of extreme events; adaptation costs associated with the practice of new cultivation techniques, and the import of seeds from other areas; and other possible effects on labor, nutrition, and health (Cochrane et al. 2009, Callaway et al. 2012).

The present study addresses the potential vulnerability of the Mediterranean mollusc aquaculture sector to climate change and ocean acidification, as well as to various other environmental pressures, through the implementation of a questionnaire developed for Mediterranean mollusc producers from several countries and regions. It first aims to assess their level of knowledge of a selected group of climatic and nonclimatic pressures, and to what extent they are perceived as a serious economic threat. Next, it collects information about the geographical spread, diversity of impacts, and adaptive measures in the context of extreme climatic episodes such as summer heat waves. Finally, it identifies the occurrence of potential future effects of ocean acidification on mollusc production, notably a decrease in shell thickness and seed recruitment. 
To our knowledge, this paper represents the first questionnairebased study of the Mediterranean bivalve mollusc aquaculture sector, and adds to the growing number of studies dealing with the socioeconomic effects of climate change and ocean acidification. Other studies involve different foci, such as economic valuation of costs (e.g., Cooley \& Doney 2009, Narita et al. 2011, Moore 2011), reviews of impacts for the aquaculture sector (e.g., Cochrane et al. 2009, Callaway et al. 2012, Rosa et al. 2012), perception and risk analysis (e.g., Ahsan and Brandt 2014, Deason et al. 2014, Hilmi et al. 2014), and policy recommendations (e.g., Washington State Blue Ribbon Panel on Ocean Acidification 2012). What sets this study apart from these is first, the focus on multiple countries in the Mediterranean Sea basin, and second, the use of both public data and questionnaire-based data to increase our understanding of the threats and impacts.

The remainder of this article is structured as follows: the section Regional Characterization of the Mediterranean Mollusc Aquaculture Sector gives a general overview of the Mediterranean mollusc aquaculture sector at a regional level. The section Questionnaire Design and Administration explains the procedures taken for the development and administration of the questionnaire to Mediterranean producers. The next section presents the results and the last section is Conclusion.

\section{REGIONAL CHARACTERIZATION OF THE MEDITERRANEAN MOLLUSC AQUACULTURE SECTOR}

Mariculture production in the Mediterranean Sea has substantially increased since the 1950s; by 2010 this six-decade increase went from 3 to 391 thousand tonnes. By 2010, mollusc aquaculture represented around $39 \%$ of total production $(\sim 151$ thousand tonnes), and $16 \%$ of the total value, i.e., $\sim 261,000$ USD of $\sim 1.7$ million USD (FAO 2010). In 2010 , $\sim 75 \%$ of the Mediterranean mollusc aquaculture was developed in marine water environments, with the remaining $25 \%$ obtained from brackish water environments (FAO 2010). Italy was the main producer in that year, responsible for $\sim 66 \%$ of total production in the area, followed by Greece $(\sim 15 \%)$, France $(\sim 13 \%)$, and Spain $(\sim 3 \%)$. The remaining countries produced only $3 \%$ jointly (FAO 2010) [Spain and France have important production zones in the Northeast Atlantic ocean. Mollusc aquaculture in this area summed $\sim 190$ and 160 thousand tonnes in 2010 for the two respective countries, respectively (FAO 2010).]. The Mediterranean mussel Mytilus galloprovincialis was the most produced species $(\sim 69 \%)$, followed by the Japanese carpet shell Ruditapes philippinarum $(\sim 23 \%)$, and a mixed group of species (e.g., other oysters and mussels, and clams) (FAO 2010).

An analysis of the distribution of mollusc production as well as its proportion of the total mariculture production (including all groups of species) was made for the Mediterranean coastal regions. This "proportion" indicator was considered as a measure of dependency of a region on mollusc aquaculture and it was obtained by dividing the production of molluscs (in tonnes) by that of total aquaculture activities in the Mediterranean Sea. Regions were classified at a Nomenclature of Territorial Units for Statistics-2 level for the European Union (EU) countries, candidates, and potential candidates [candidates include Albania, Montenegro, and Turkey, and potential candidates Bosnia and Herzegovina (EU 2014)], and as similar administrative territories (e.g., Governorates, Provinces, Wilayas) for the remaining countries (Table A1). Figures 1 and 2 present the results for 2010 (supported by data available in Table A2). Mollusc production is concentrated in the Northern-rim countries, notably Italy, Greece, France, and Spain. All Adriatic countries also produce molluscs. In a descending order of relevance these include Italy $(88 \%$ of its production is in the Adriatic Sea), Croatia, Albania, Montenegro, Slovenia, and Bosnia and Herzegovina. From the group of Eastern-rim countries, only Turkey has some production, whereas the Southern-rim countries are only represented by Tunisia and Morocco. (Northern-rim countries are Albania, Bosnia and Herzegovina, Croatia, France, Greece, Italy, Malta, Monaco, Montenegro, Slovenia, and Spain. Eastern-rim countries are Cyprus, Israel, Lebanon, Palestinian Territories, Syria, and Turkey. Southern-rim countries are Algeria, Egypt, Libya, Morocco, and Tunisia.) In terms of regions, the five main producers in a descending order of magnitude are Emilia Romagna and Veneto (Italy), Kentriki Makedonia (Greece), Languedoc-Roussillon (France), and Puglia (Italy), representing $\sim 74 \%$ of the entire production. In all of these regions, mollusc production represents a high proportion of total mariculture, with percentages equal to or higher than $78 \%$.

\section{QUESTIONNAIRE DESIGN AND ADMINISTRATION}

A structured questionnaire was distributed among Mediterranean mollusc aquaculture producers with the purpose of assessing their knowledge, opinions and practices in the context of climatic and nonclimatic pressures potentially affecting the sector. Special attention was given to extreme events such as summer heat waves and certain effects that might be expected under ocean acidification (e.g., decreases in shell thickness/ resistance and in seed recruitment).

The questionnaire had the following structure: it opened with basic questions on the characteristics of the aquaculture firms (e.g., location, years of establishment, and the number of the staff used). Next, questions were asked on production and markets (e.g., area of production, total produced quantity per species, and total sales). This was followed by questions about various environmental issues (e.g., knowledge and perception about environmental threats, types of damages observed in the past, adaptive measures taken). The questionnaire was translated into several languages (English, Spanish, French, Italian, Croatian, and Greek) to be distributed to producers through an online web platform and E-mail (The complete version of questionnaire is available at http:// www.online-research-survey.com/index.php/215493/lang-en.).

It was anticipated that collecting answers from individual producers in different countries would not be easy. Producers were mainly indirectly reached through a process of so-called "snowball sampling" (Bryman 2008). Several local points of contact within the aquaculture technical networks of the General Fisheries Commission of Mediterranean of Food and Agriculture Organization of United Nations, producers associations and cooperatives, universities and research centers, and municipality offices, served as interlocutors with the producers from different countries. Furthermore, as a complementary strategy, producers were also contacted directly in person or by phone to ask for their participation in the study.

\section{RESULTS}

\section{Surveyed Areas}

A total of 49 surveys were answered between October 2013 and November 2014. These answers came from producers from 


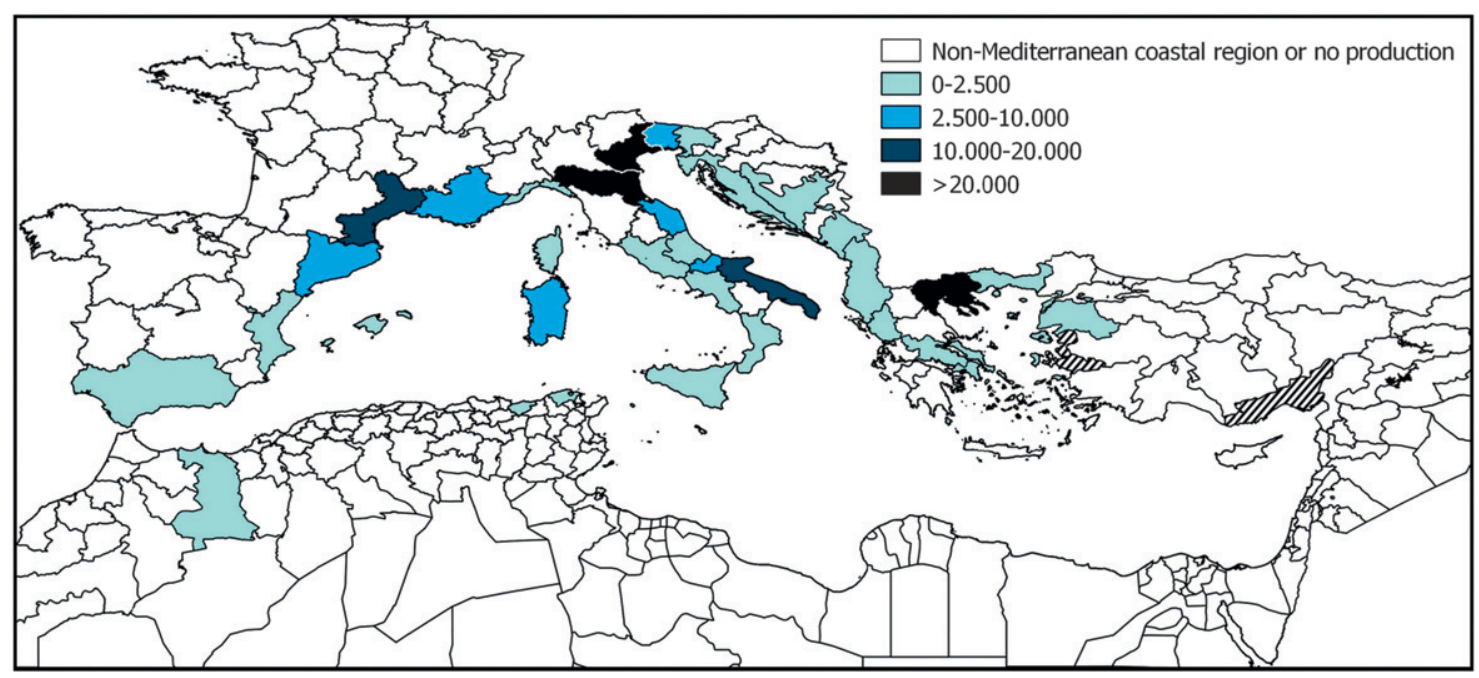

Figure 1. Regional production of aquaculture molluscs (tonnes, 2010). Source: Information provided by the Associazione Mediterranea Acquacoltori (AMA); Campbell and Pauly (2013); CEPRALMAR (2011); Magrama (2010); FAO (2010); Theodorou et al. (2011); European Commission (2009); and the Slovenian Hunting and Fisheries Division, Ministry of Agriculture and the Environment of Slovenia. Note: Data were not available for the regions of Izmir and Adana in Turkey despite Candan et al. (2007) and Lök (2009) indicating the existence of mollusc aquaculture farms in these regions.

12 coastal regions and six Mediterranean countries, namely: Catalonia (Spain); Languedoc-Roussillon (France); Veneto, Friuli-Venezia Giula, Puglia, and Marche (Italy); Montenegro; Kentriki Makedonia, Anatoliki Makedonia and Thraki, Ipeiros, and Sterea Ellada (Greece), and Bizerte (Tunisia). These regions are quite diverse in terms of production and regional dependency on mollusc production. In particular, some regions are top producers, whose aquaculture activities rely almost exclusively on molluscs (e.g., Languedoc-Roussillon \& Veneto), whereas others present lower levels of production and dependency (e.g., Ipeiros) (Fig. 3; Table A2).

The majority of the selected regions are represented by a single production site, whereas others such as LanguedocRoussilon (France), Anatoliki Makedonia and Thraki
(Greece), Ipeiros (Greece), and Marche (Italy) have two production sites figuring in the study. Altogether, 16 production sites were reached, including sites located in different environments such as lagoons, coastal zones/bays, and offshore areas. All sites produce Mediterranean mussel, whereas some also cultivate other species, such as oysters and clams, inter alia, Ebro delta (Catalonia, Spain), Civitanova coast (Marche, Italy), and Etang de Thau (Languedoc-Roussillon, France). The number of responses per production site ranged from 1 to 9 , with an average representativeness in terms of total producers per site of $22 \%$, and lower and upper bounds of representativeness of $1 \%$ (Etang de Thau, France) and 56\% (Gulf of Kotor, Montenegro), respectively (Table 1). Despite having relatively few responses among producers, Etang de Thau

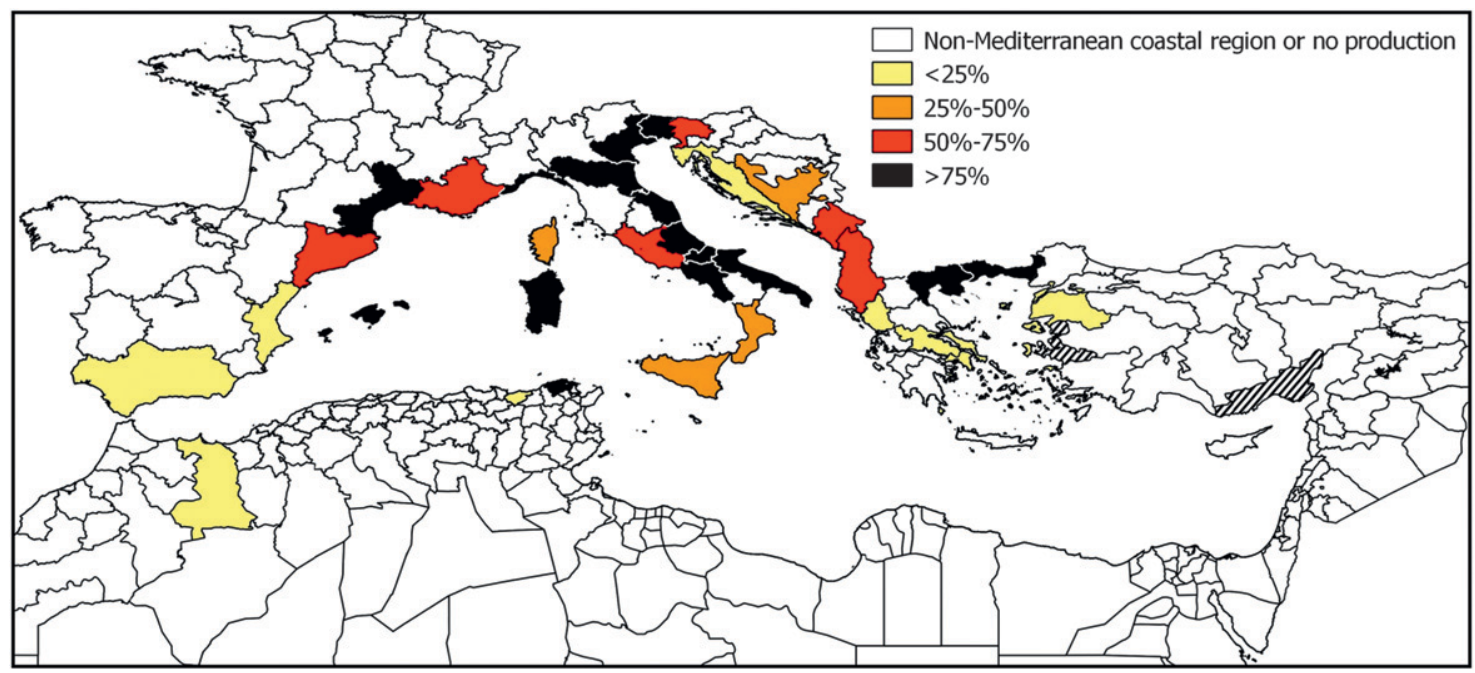

Figure 2. Dependency of regional aquaculture on molluscs (\%, 2010). Source: Information provided by the Associazione Mediterranea Acquacoltori (AMA); the Decentralized Peripheral Administration of Kentriki Makedonia, Thraki; Campbell and Pauly (2013); CEPRALMAR (2011); Magrama (2010); FAO (2010); Theodorou et al. (2011); European Commission (2009); and the Slovenian Hunting and Fisheries Division, Ministry of Agriculture and the Environment, Slovenia. Note: No data were available for the regions of Izmir and Adana in Turkey. 


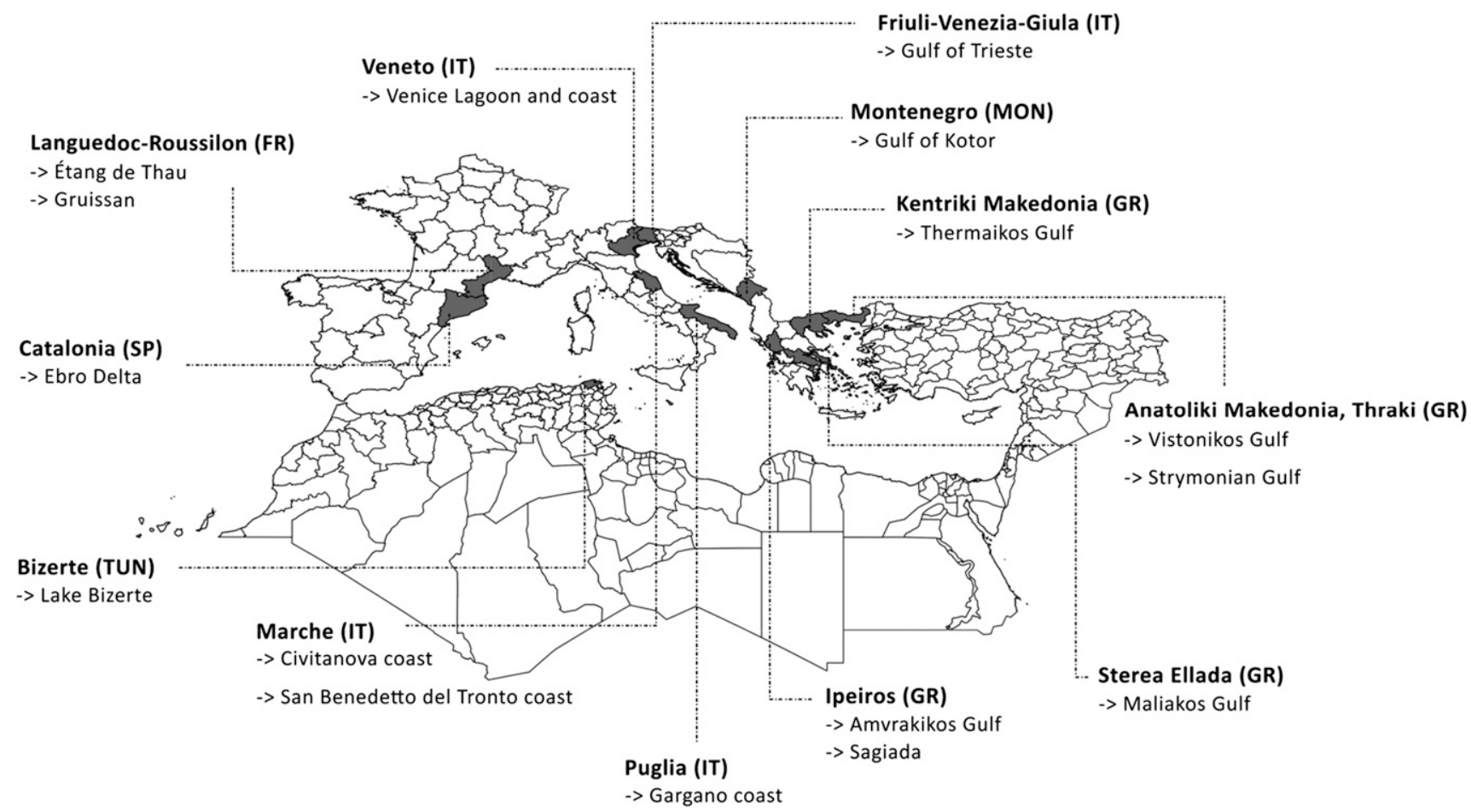

Figure 3. Regions and production sites. Abbreviations have the following meaning: Fr, France; GR, Greece; IT, Italy; MON, Montenegro; SP, Spain; TUN, Tunisia.

(France) and Venice Lagoon and coast (Italy) were included in the analysis to also capture impacts occurring in these areas.

Table 2 shows that the mean age of establishment of mollusc farms is $17 \mathrm{y}$, the mean production area is of $\sim 20$ ha per farm, and the number of full-time employees ranges from a minimum of 0 to a maximum of 45 . The Mediterranean mussel is the most produced species represented in the survey with a total of 5.6 thousand tonnes and an average of $\sim 117$ tonnes per farm in 2012, followed by the Pacific cupped oyster that amounted to a total of 542 tonnes and $\sim 12$ tonnes per farm. In total, sampled farms reach $\sim 6.2$ thousand tonnes of produced molluscs, representing $4.1 \%$ of the entire Mediterranean production. The mean level of total annual sales is close to $€ 50,000$ per farm.

\section{Knowledge and Perception of Threat Posed by Environmental Pressures}

Producers were asked to indicate their knowledge level and to provide a risk assessment on a total of nine environmental pressures:

- Gradual increase in SST due to climate change

- Summer heat waves leading to abrupt increases of seawater temperature

- Ocean acidification

- Sea level rise

- Marine pollution

- Mollusc diseases

- Eutrophication

- HAB

- Invasive species

Producers had the possibility to classify these potential threats according to their following levels of knowledge: "good", "limited", or "I never heard about this pressure". Figure 4 indicates that ocean acidification was the most unknown pressure with $47 \%$ of the respondents who never heard of it. Furthermore, $14 \%$ of the respondents did not answer this question revealing a certain lack of knowledge as well. Summer heat waves were associated with a higher level of knowledge, with about $63 \%$ of the respondents stating to have a good knowledge about this pressure. Other pressures reaching a high level of good knowledge were $\mathrm{HAB}$, gradual increase in SST, and eutrophication.

Following a brief text describing each of these environmental pressures (Box A1), producers were asked to answer two questions, notably about their perceived level of threat to their activity, according to the levels "high", "moderate", and "low", and about potential changes in their perceptions of threat influenced by the reading of the informative text. Accordingly, Figure 5 indicates that a great majority of the respondents $(76 \%)$ consider heat waves as a high threat, whereas about $51 \%$ and $45 \%$ selected the same level of threat for $\mathrm{HAB}$ and for gradual increase in SST, respectively. Ocean acidification and sea level rise were the pressures the least classified as a high threat (12\% and $4 \%$, respectively). Finally, regarding ocean acidification and invasive species, respectively, $53 \%$ and $43 \%$ of the respondents either did not reply or did not know how to classify these pressures.

A specific analysis per production site available in Table 3 shows that summer heat waves and $\mathrm{HAB}$ were classified as a high threat for 11 and 10 production sites, respectively. On the contrary, sea level rise was perceived as the lowest threat with levels of moderate and low threat for 3 and 12 sites, respectively. Ocean acidification was the second pressure less perceived as harmful, being considered as a high threat only for two sites, namely Etang de Thau (France) and Civitanova (Italy), moderate for 4 sites, and low threat for 7 sites.

The assessment of changes in the perception about the level of risk shown in Figure 6 indicates that a significant part changed their opinion about the respective levels of threat to their activity 
TABLE 1.

Characteristics of the production sites.

\begin{tabular}{|c|c|c|c|c|c|c|}
\hline Production sites & Region & Country & Environment & Produced species & $\begin{array}{l}\text { Number } \\
\text { of answers }\end{array}$ & $\begin{array}{l}\text { Representativeness } \\
\text { (\% over total } \\
\text { number of } \\
\text { producers per site) }\end{array}$ \\
\hline Etang de Thau & Languedoc-Roussillon & FR & Lagoon; coast/bay & MM; PCO & 6 & $1.2 \% *$ \\
\hline Gruissan & Languedoc-Roussillon & FR & Coast/bay & MM; PCO & 1 & $25 \% *$ \\
\hline Vistonikos Gulf & $\begin{array}{l}\text { Anatoliki Makedonia, } \\
\text { Thraki }\end{array}$ & GR & Offshore & $\mathrm{MM}$ & 1 & $20 \% \uparrow \S$ \\
\hline Strymonian Gulf & $\begin{array}{l}\text { Anatoliki Makedonia, } \\
\text { Thraki }\end{array}$ & GR & Coast/bay & MM; EFO & 1 & $12.5 \% \ddagger$ \\
\hline Sagiada (Kalamas Delta) & Ipeiros & GR & Coast/bay & MM & 1 & $12.5 \% \dagger \S$ \\
\hline Amvrakikos Gulf & Ipeiros & GR & Semi-enclosed embayment & MM & 1 & $14.3 \%$ \\
\hline Thermaikos Gulf & Kentriki Makedonia & GR & Coast/bay; offshore & MM & 9 & $6.1 \% \|$ \\
\hline Maliakos Gulf & Sterea Ellada & GR & Coast/bay & MM & 3 & $30 \% \S$ \\
\hline Gulf of Trieste & Friuli-Venezia-Giula & IT & Coast/bay & MM & 1 & $6.3 \% * *$ \\
\hline $\begin{array}{l}\text { San Benedetto del Tronto } \\
\text { coast }\end{array}$ & Marche & IT & Offshore & MM; EFO & 2 & $50 \%+\dagger$ \\
\hline Civitanova coast & Marche & IT & Offshore & MM; EFO; PCO & 1 & $10 \% \dagger \dagger$ \\
\hline Gargano coast & Puglia & IT & Offshore & MM & 2 & $40 \%+\hbar$ \\
\hline Venice Lagoon and coast & Veneto & IT & Lagoon; offshore & MM & 1 & $0.9 \%-3.8 \% \S \S$ \\
\hline Gulf of Kotor & Montenegro & MON & Coast/bay; offshore & $\mathrm{MM} ; \mathrm{EFO}$ & 9 & $56.3 \%$ ฯ \\
\hline Ebro Delta & Catalonia & SP & Lagoon; offshore & MM; PCO; GCS; JCS & 6 & $13.3 \%\|\| \mid$ \\
\hline Lake Bizerte & Bizerte & TUN & Lagoon & $\mathrm{MM}$; PCO & 4 & $33.3 \% * * *$ \\
\hline
\end{tabular}

For the column referring to Country, abbreviations have the following meaning: FR, France; GR, Greece; IT, Italy; MON, Montenegro; SP, Spain; TUN, Tunisia; for the column referring to Produced species, abbreviations have the following meaning: MM, Mediterranean mussel; PCO, Pacific cupped oyster; EFO, European flat oyster; JPS, Japanese carpet shell; for the production site located in Venice Lagoon and coast, the lower bound in the representativeness column corresponds to the estimates for the surrounding municipalities of the Venice Lagoon, whereas the higher bound corresponds to the municipality of Venice.

* CRCM (2014) and personal information provided by CRCM (Comité Régional Conchylicole de Méditerranée, France, http://www.srcm.fr). $\dagger$ Ministry of Rural Development and Food, Hellenic Republic (2014).

$\$$ Personal information provided by the local fisheries authorities of the Prefectures of Chalikidiki, Kavala, and Serres.

$\S$ Theodorou et al. (2011).

I Personal communication with local producers.

| Personal information provided by the Department of Fisheries and Aquaculture, Decentralized Peripheral Administration of Kentriki Makedonia, Thraki.

** Melaku Canu and Solidoro (2013).

$\dagger \dagger$ Regione Marche (2008).

ț Giuffrè et al. (2012).

$\S \S$ Comité National de la Conchyliculture (2013).

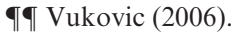

||l| Personal information provided by FEPROMODEL.

*** Personal information provided by the Direction Générale de la Pêche et de l'Aquaculture (DGPA).

after reading the proposed text describing these environmental pressures. Most relevant changes were associated with ocean acidification, summer heat waves, gradual increase in SST, and HAB. About $31 \%$ of the producers were influenced by the text and after reading it consider ocean acidification as a serious threat, whereas $25 \%$ of producers observed the same change for summer heat waves, and $21 \%$ for the two remaining pressures. On the contrary, the percentage of producers changing towards the opinion that the studied pressures will not represent a serious threat ranged from $2 \%$ for $\mathrm{HAB}$ and gradual increase in SST to $8 \%$ for marine pollution. With regard to summer heat waves none of the respondents changed their opinion towards not considering it a serious threat.

Finally, producers were asked to indicate any environmental problem in addition to the nine stressors previously documented, affecting their activity. Suggestions given included: threats coming from other species (e.g., turtles, sea snails, hydrozoans, fish species like sea bream damaging molluscs) (seven producers); extreme events like floods (rain falls anomalies with strong inflows of freshwater) (one producer), and storms characterized by strong winds, high waves and strong ocean currents (one producer); and changes in water salinity (one producer).

\section{Information on Summer Heat Waves Events}

The majority of respondents $(\sim 78 \%)$ admitted having experienced important difficulties in their activity in the past years as a consequence of summer heat waves. Figure 7 shows the geographical distribution of heat waves occurring in the past years in the case study regions and provides information about the types of damage observed. These events were observed for 13 out of a total of 16 production sites on several occasions during 
TABLE 2.

Characteristics of the respondents.

\begin{tabular}{|c|c|c|c|c|c|c|}
\hline & $\mathbf{n}$ & Minimum & Maximum & Mean & SD & Total \\
\hline \multicolumn{7}{|l|}{ General characteristics } \\
\hline Age of establishment* & 39 & 2 & 78 & 17 & 15.8 & - \\
\hline Area of production (ha)* & 45 & 0.0023 & 206.7 & 19.9 & 50.3 & 896.3 \\
\hline Staff used (number of full-time employees) $\dagger$ & 47 & 0 & 45 & 5 & 7.3 & 212 \\
\hline Total annual salesti & 48 & 1 & 7 & 2.8 & 1.9 & - \\
\hline \multicolumn{7}{|l|}{ Production (tonnes) $\dagger$} \\
\hline Mediterranean mussel & 48 & 0 & 1,200 & 117.1 & 205.5 & 5,621 \\
\hline Pacific cupped oyster & 47 & 0 & 150 & 11.5 & 30.8 & 542 \\
\hline Other species & 49 & 0 & 10 & 0.4 & 1.6 & 20 \\
\hline \multicolumn{6}{|l|}{ Total production (tonnes) $\dagger$} & 6,183 \\
\hline \multicolumn{6}{|c|}{$\%$ Over total Mediterranean mollusc aquaculture§ } & $4.1 \%$ \\
\hline
\end{tabular}

* Information corresponds to the years 2013/2014.

$\dagger$ Information corresponds to the year 2012 .

$\ddagger 1=<€ 25,000 ; 2=€ 25,000-€ 50,000 ; 3=€ 50,000-€ 100,000 ; 4=€ 100,000-€ 200,000 ; 5=€ 200,000-€ 300,000 ; 6=€ 300,000-€ 400,000 ;$ $7>€ 400,000$.

$\S$ Data from 2010 (FAO 2010) was considered for the total Mediterranean production.

the last two decades and occurred in different production environments such as lagoons, coastal areas, and bays. Regarding the description of the effects caused by heat waves, some producers pointed out that molluscs were sensitive to temperatures exceeding $28-31^{\circ} \mathrm{C}$, leading to mortalities of seed or adult molluscs, reaching in some cases up to $100 \%$ of the total stock. Furthermore, another observed effect was a decrease in byssus, which affects the ability of molluscs to attach to the production ropes. According to producers from the regions of LanguedocRoussillon (France) and Marche (Italy), this problem is not only due to temperature, but to a combination with other stressors, such as lack of oxygen and unfavorable wind and sea conditions.

Producers were further asked to indicate which types of measures were taken to respond to summer heat wave events. The most repeated answer was moving the production to deeper water areas (13 producers) and collecting and selling mussels before the usual period (11 producers), followed by the option of hiring an insurance company (4 producers), which was exclusive from Ebro Delta (Spain), "no action/no solution" (5 producers), reducing eutrophication sources (1 producer), importing seed
(1 producer), delaying sowing (1 producer), and cleaning the production ropes (1 producer).

Summer heat waves create various types of damage costs. According to a producer from Ebro Delta River (Agustí Bertomeu, personal communication, January 2014), a heat wave event that occurred in 2013 led to an aggregated loss of 900 tonnes of Mediterranean mussel in this production area, corresponding to a cost of $\sim € 0.9$ million. Before attaching new seeds to the ropes, producers had to import mussel seeds from other countries (costing around $€ 0.9-€ 1$ per $\mathrm{kg}$ ), clean the current ropes containing dead mussels, and treat the resulting waste, with an overall cost of $€ 40,000 € 50,000$. Although this is a rough estimate, the previous description serves as an illustration of how producers are economically affected by heat waves.

\section{Information on the Decrease of Seed Recruitment and Shell Thickness/ Resistance}

Figure 8 gives information on the percentages of seed recruitment for each production site according to different

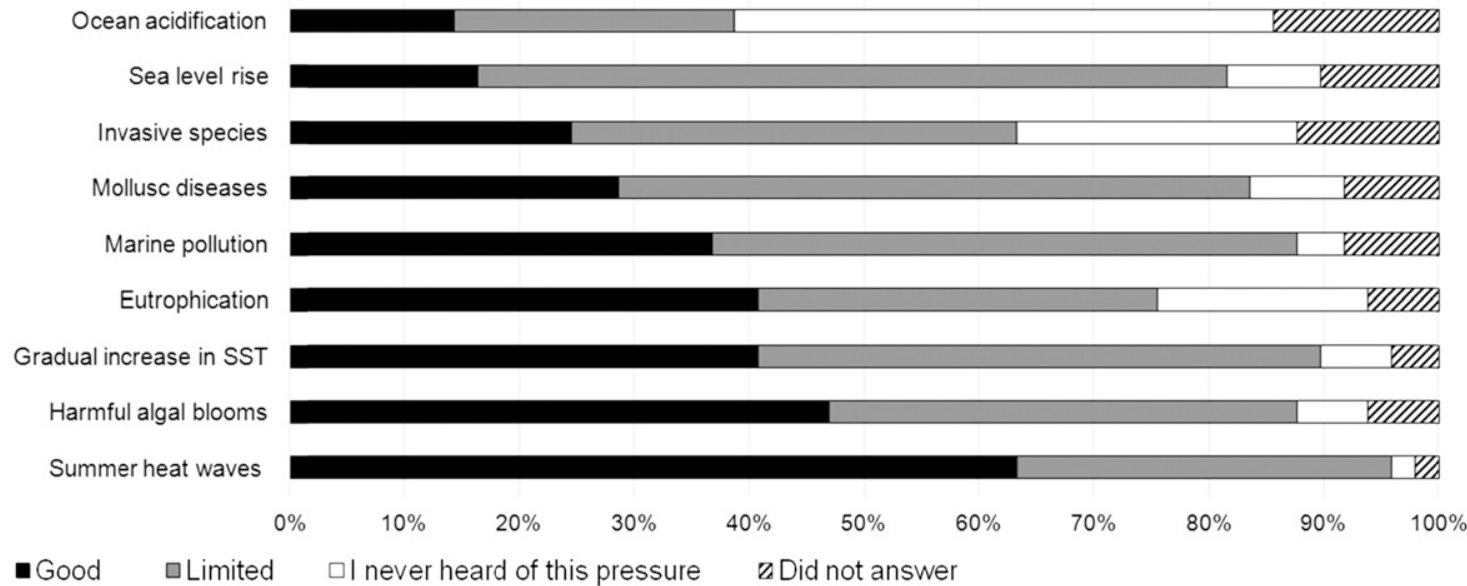

Figure 4. Level of knowledge about environmental pressures. 


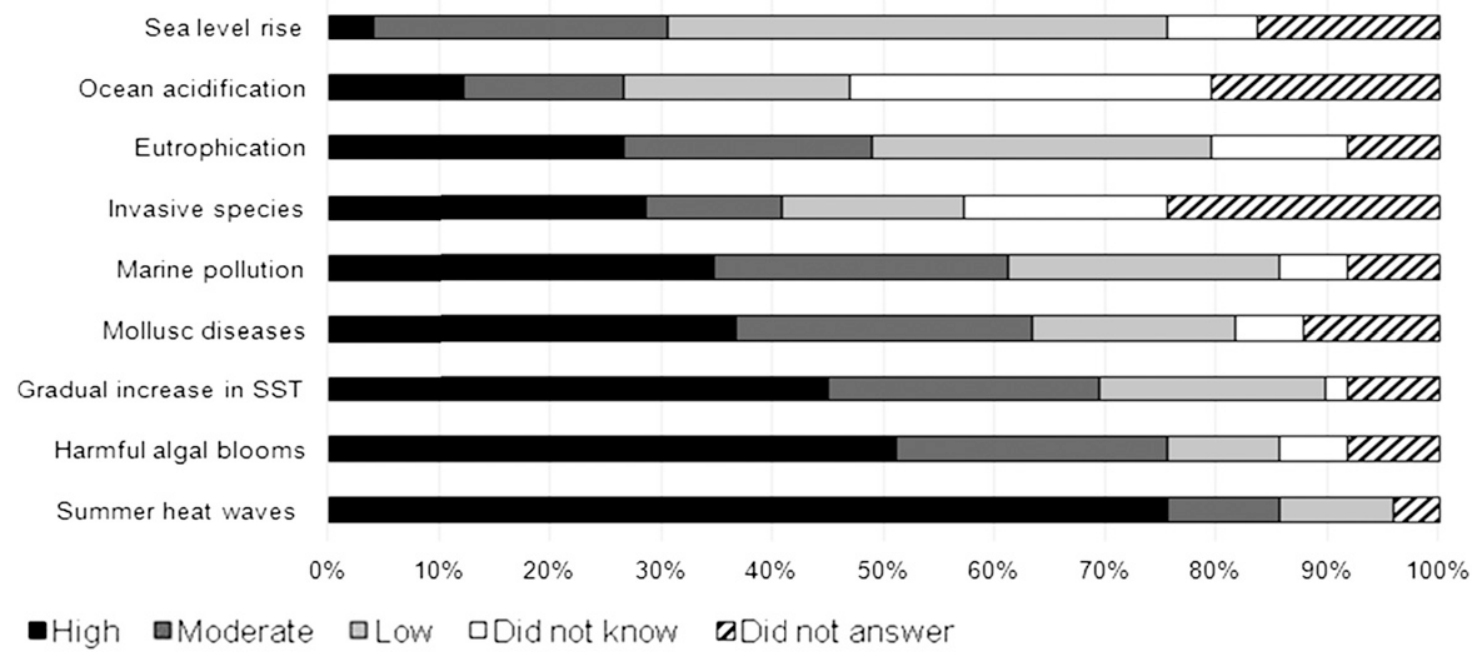

Figure 5. Opinions on level of threat posed by environmental pressures.

sources, namely natural environment near the culture location, through imported seeds, and through hatchery. Furthermore, it shows which production sites have in past years shown an alteration of larval development (decrease in seed recruitment) and shell production (decrease in shell thickness/resistance), both of which are expected under ocean acidification (e.g., Kroeker et al. 2013, Gazeau et al. 2013).

Results show that the majority of the producers rely on the recruitment of mussel seeds from the natural environment near the culture location. Considering all producers combined, about $80 \%$ of seeds come from this source, whereas $15 \%$ are imported, and 5\% are obtained from hatcheries. Regarding oysters, a majority $(62 \%)$ of the seeds are imported, $25 \%$ are produced in a hatchery, and only $13 \%$ are obtained in the natural environment near the production location. A specific analysis by production site indicates that some farms located in Sagiada (Ipeiros, Greece), and in the Strymonian Gulf (Anatoliki Makedonia, Thraki, Greece) totally depend on imported seeds.

The decrease in seed recruitment was indicated to have happened in past years by $37 \%$ of the producers in areas such as Etang de Thau and Gruissan (Languedoc-Roussillon, France), Ebro Delta (Catalonia, Spain), Thermaikos Gulf (Kentriki Makedonia, Greece), Maliakos Gulf (Ipeiros, Greece), and Vistonikos Gulf (Anatoliki Makedonia, Thraki, Greece). Nevertheless, producers indicating such problems also stated that it was likely caused by other stressors (e.g., virus proliferation and sea bream). A decrease in shell thickness/resistance was observed in Etang de Thau (Languedoc-Roussillon, France), Lake Bizerte (Bizerte, Tunisia), the Civitanova Marche coast (Marche, Italy), the Gulf of Trieste (Friuli-Venezia-Giula, Italy), the Gulf of Kotor (Montenegro), the Maliakos Gulf (Sterea Ellada, Greece), and in the Thermaikos Gulf (Kentriki Makedonia, Greece), and reported by $34 \%$ of all producers.

\section{CONCLUSIONS}

Bivalve mollusc aquaculture is present in many parts of the Mediterranean Sea, with important production sites in Italy, Greece, and France. It is performed in a diversity of sites, including lagoons, bays, and offshore areas, and following different techniques, such as long lines and floating rafts. The cultivation of molluscs depends on a fine balance between environmental factors that are currently under pressure from climate change and ocean acidification. This study aimed to understand how producers from different Mediterranean sites assess a selected group of climatic and nonclimatic pressures, in terms of knowledge, perception of threat, and impacts on their activity.

Results show that there is a high uncertainty and lack of knowledge among producers regarding what ocean acidification could represent for the future of their sector. This pressure was classified as the lowest threat after sea level rise. More familiar pressures included eutrophication, marine pollution, gradual increase in SST and summer heat waves. The latter pressure represents an important concern of mollusc producers, being classified as the highest threat. In the analysis developed in this study, the inclusion of an informative text about the environmental pressures in the questionnaire motivated changes in the perceptions of producers. This indicates that the provision of more information about climatic and nonclimatic pressures could be beneficial for the mollusc sector in anticipating and adapting to such problems.

Regarding the observation of impacts, summer heat waves have occurred in a great number of production sites in the past years with detrimental effects on cultivated species including seed availability and adult mortality, as well as a decrease in the production of byssus. Economic effects comprised revenue losses associated with the mortality of farmed species as well as adaptation costs taken to restart the production. Frequently adopted measures to respond to such events involve moving the production to bigger depths or expediting harvest and sales. In contrast, effects such as a decrease in shell resistance/thickness were observed in fewer production sites with no evidence, according to the producers, that it is caused by ocean acidification. Various producers indicate that production losses also arise from the influence of other pressures, including predators, storms, and floods.

Another point that deserves attention is the origin of seeds. The larval stage represents one of the most vulnerable periods 
TABLE 3.

Threat levels for environmental pressures for all production sites.

\begin{tabular}{|c|c|c|c|c|c|c|c|c|c|}
\hline & & High & Moderate & Low & No classi & ion (no ans & r, do not know) & & \\
\hline $\begin{array}{l}\text { Production } \\
\text { sites }\end{array}$ & $\begin{array}{c}\text { Gradual } \\
\text { increase in } \\
\text { SST }\end{array}$ & $\begin{array}{c}\text { Summer } \\
\text { heat waves }\end{array}$ & $\begin{array}{c}\text { Ocean } \\
\text { acidification }\end{array}$ & Sea level rise & $\begin{array}{c}\text { Marine } \\
\text { pollution }\end{array}$ & $\begin{array}{l}\text { Mollusc } \\
\text { diseases }\end{array}$ & Eutrophication & HAB & $\begin{array}{c}\text { Invasive } \\
\text { species }\end{array}$ \\
\hline $\begin{array}{l}\text { Etang de } \\
\text { Thau (FR) }\end{array}$ & & & & & & & & & \\
\hline $\begin{array}{l}\text { Gruissan } \\
\text { (FR) }\end{array}$ & & & & & & & & & \\
\hline $\begin{array}{l}\text { Vistonikos } \\
\text { Gulf (GR) }\end{array}$ & & & & & & & & & \\
\hline $\begin{array}{l}\text { Strymonian } \\
\text { Gulf (GR) }\end{array}$ & & & & & & & & & \\
\hline $\begin{array}{l}\text { Sagiada } \\
\text { (Kalamas } \\
\text { delta) (GR) }\end{array}$ & & & & & & & & & \\
\hline $\begin{array}{l}\text { Amvrakikos } \\
\text { Gulf (GR) }\end{array}$ & & & & & & & & & \\
\hline $\begin{array}{l}\text { Thermaikos } \\
\text { Gulf (GR) }\end{array}$ & & & & & & & & & \\
\hline $\begin{array}{l}\text { Maliakos } \\
\text { Gulf (GR) }\end{array}$ & & & & & & & & & \\
\hline $\begin{array}{l}\text { Gulf of } \\
\text { Trieste (IT) }\end{array}$ & & & & & & & & & \\
\hline $\begin{array}{l}\text { S. } \\
\text { Benedetto } \\
\text { del Tronto } \\
\text { coast (IT) }\end{array}$ & & & & & & & & & \\
\hline $\begin{array}{l}\text { Civitanova } \\
\text { coast (IT) }\end{array}$ & & & & & & & & & \\
\hline $\begin{array}{l}\text { Gargano } \\
\text { coast (IT) }\end{array}$ & & & & & & & & & \\
\hline $\begin{array}{l}\text { Venice } \\
\text { Lagoon and } \\
\text { coast (IT) }\end{array}$ & & & & & & & & & \\
\hline $\begin{array}{l}\text { Gulf of } \\
\text { Kotor } \\
(\mathrm{MON}) \\
\end{array}$ & & & & & & & & & \\
\hline $\begin{array}{l}\text { Ebro Delta } \\
\text { (SP) }\end{array}$ & & & & & & & & & \\
\hline $\begin{array}{l}\text { Lake } \\
\text { Bizerte } \\
\text { (TUN) }\end{array}$ & & & & & & & & & \\
\hline
\end{tabular}

For the column referring to Production sites, abbreviations have the following meaning: FR, France; GR, Greece; IT, Italy; MON, Montenegro; SP, Spain; TUN, Tunisia.

in mollusc development to climate change and ocean acidification (e.g., Gazeau et al. 2013). Mollusc farms experiencing a decrease in the recruitment from the natural environment near production sites in the future may need to turn to other sources such as hatcheries or importing from other areas, which may represent supplementary operational costs. The latter option could mean a possible dependency of producers on other distant areas. Here it may be noted that the current EU legislation restricts seed transfer from site to site for zoosanitary reasons. In view of this, the health status of each farming area has to be properly monitored and risk assessments have to be developed (Muehlbauer et al. 2014, Brenner et al. 2014), so as to solve the problem of seed supply (e.g., to release seed transfer from a higher health status area to a lower status area).

Important gaps still exist in the knowledge about the impacts of climatic change and ocean acidification on species' physiology and adaptive capacity, synergies with other stressors, and ecosystem-wide implications; however, it is clear that these global threats are likely to become more pronounced in the coming decades, potentially affecting sea-based sectors such as mollusc aquaculture. This paper represents a solid step towards future cooperation between academics and producers. Approximately $94 \%$ of the producers assessed in the study stated in the final part of the questionnaire that they were willing to collaborate on the improvement of the projections on future effects of climate change and ocean acidification on the mollusc aquaculture industry.

\section{ACKNOWLEDGMENTS}

This study is part of the project "European Mediterranean Sea Acidification in a changing climate" (MedSeA), funded by the European Commission under Framework Program 7 (http://medsea-project.eu). We would like to thank all the 


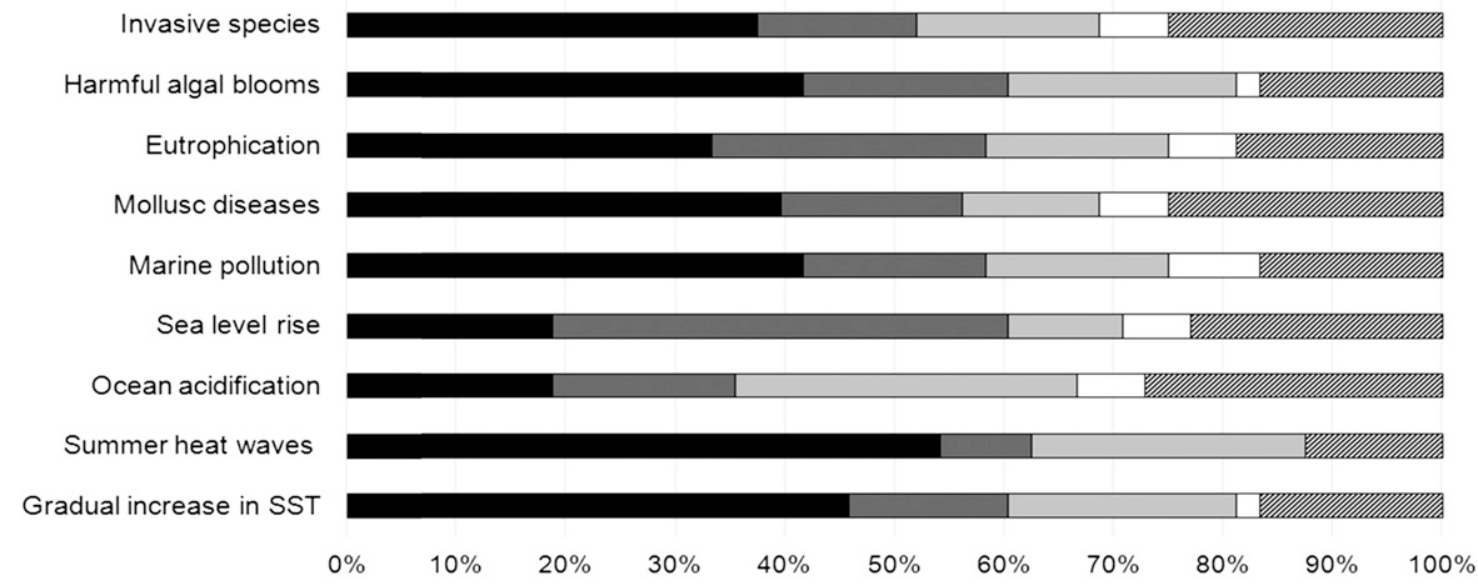

No, it did not change my perception. This pressure will be a threat to my activity

$\square$ No, it did not change my perception. This pressure is NOT a serious problem for my activity

$\square$ Yes, I do believe now that this pressure is a serious problem for my activity

$\square$ Yes, I do believe now that this pressure is NOT a serious problem for my activity

$\mathbb{2}$ Did not answer

Figure 6. Change in the perception of producers regarding the risk of environmental pressures after reading an informative text about these.

producers for participating in the study, and the following persons for helping out with the questionnaire design and administration, or providing information about the mollusc sector or other relevant data: Agustí Bertomeu, Adriana
Nicosia, Adriano Agnelli, Alexandra Papathanasiou, Alessandro Meluni, Annelies Broekman, Cosimo Solidoro, Denis Regler, Donata Melaku Canu, Emanuele Rossetti, Eraldo Rambaldi, Eva Krasakopoulou, Frangoulis Constantin,

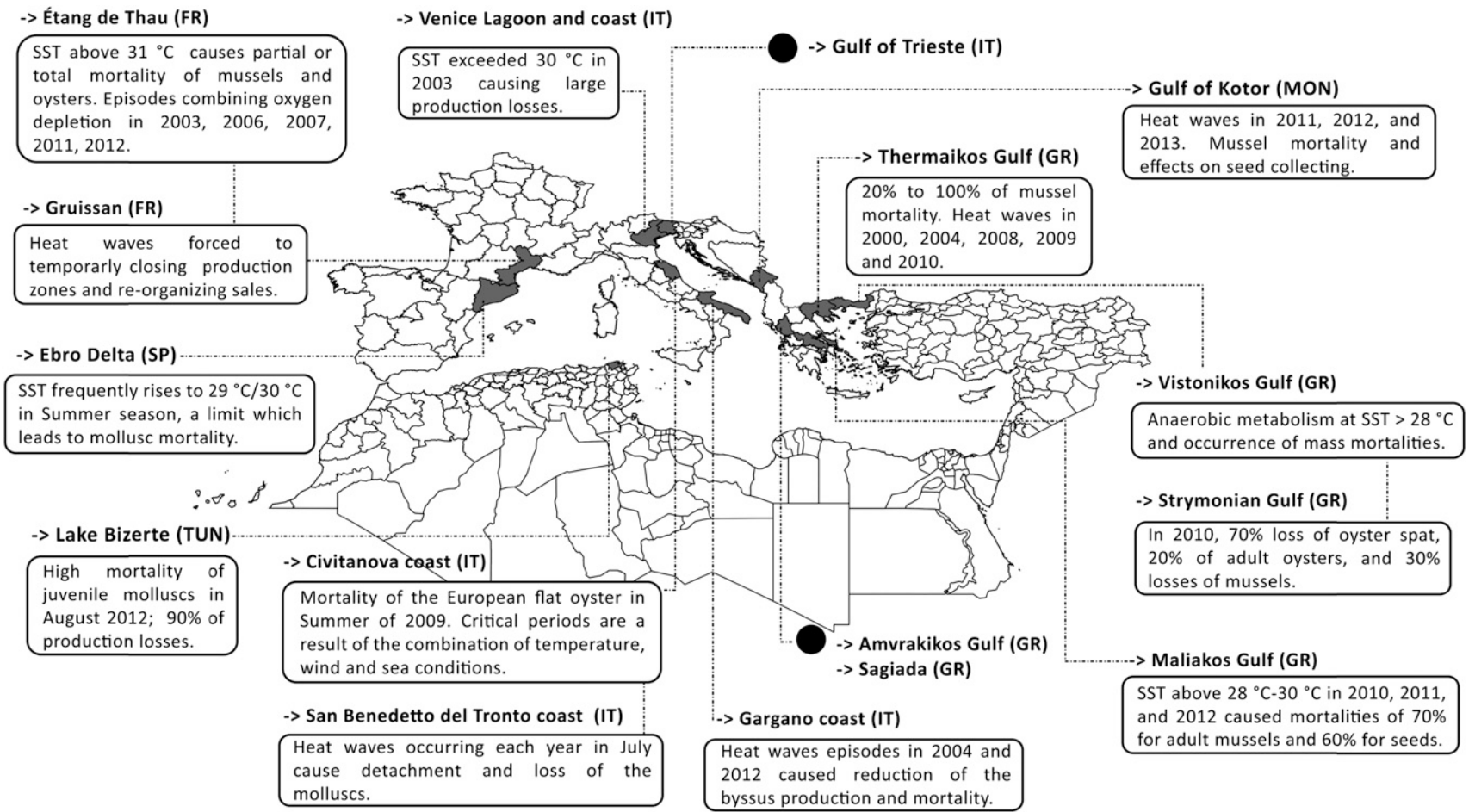

No effects were observed

Figure 7. Summer heat wave events in the Mediterranean Sea area during the past two decades. 


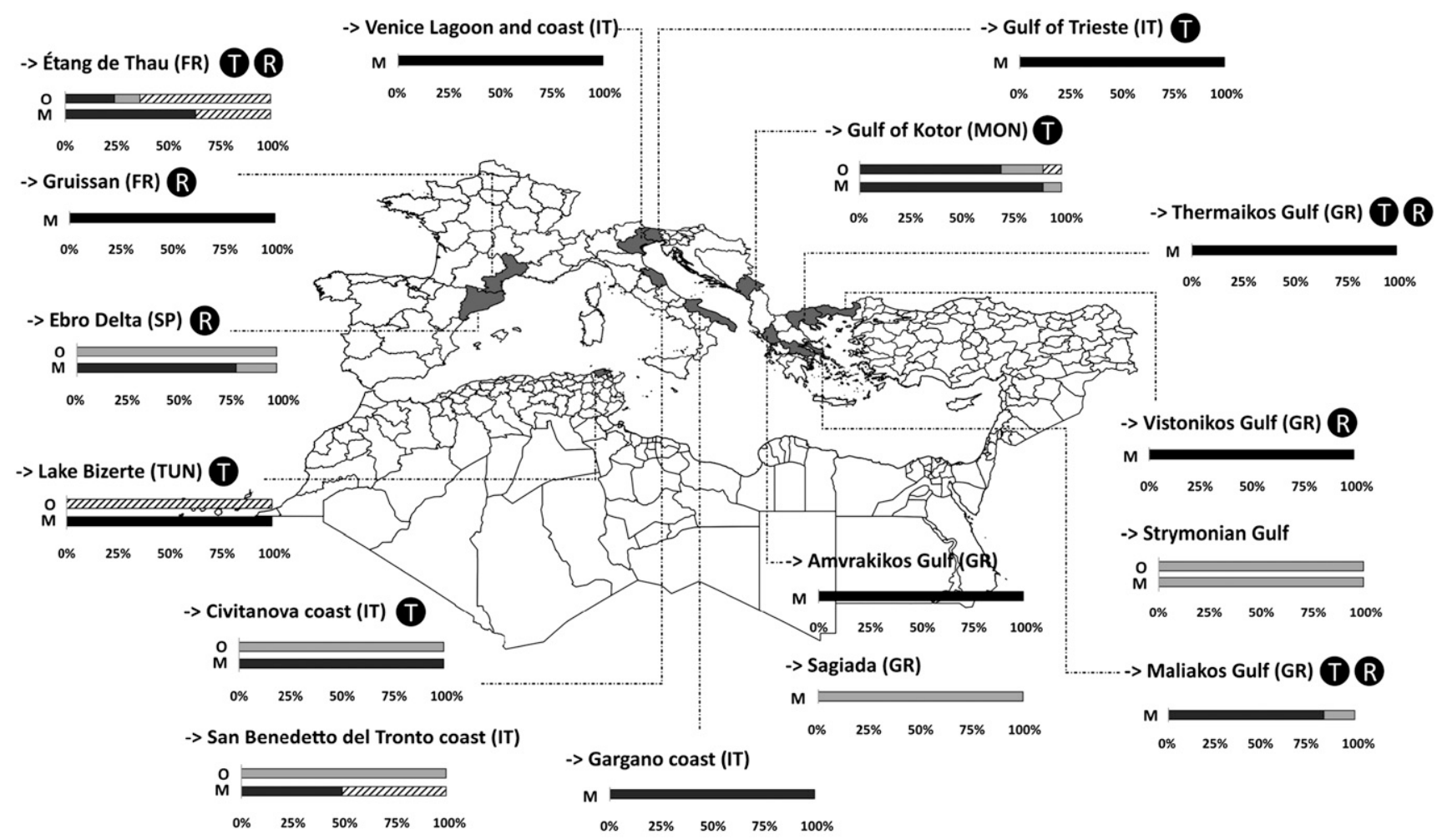

1. Seed recruitment source for mussels $(\mathrm{M})$ and oysters $(\mathrm{O})(\%)$ :

Natural environment near the production areas

Imported seeds from the natural environment

Hatchery

2. Observation of effects:

R Decrease in seed recruitment $\mathrm{T}$

Decrease in shell thickness / resistance

Figure 8. Experienced decreases of shell thickness/resistance and seed recruitment in past years.

Gerardo Bonet, Giuseppe Prioli, Houssam Hamza, Ivana Logar, Ivar Revke, Jovanka Špirić, Luís Fernandes, Marta García Sierra, Maarten van Rouveroy, Mari Carmen Berrio, Massimo
Rampacci, Milica Mandic, Mimoza Cobani, Nikos Stamoudis, Panagiota Katikou, Panagiotis Angelidis, Paolo Lazzari, Paulo Nunes, Peter Graham Mortyn, and Polona Bunič.

\section{LITERATURE CITED}

Ahsan, D. \& U. S. Brandt. 2014. Climate change and coastal aquaculture farmers' risk perceptions: experiences from Bangladesh and Denmark. J. Environ. Plann. Manage., doi: 10.1080 09640568.2014.942414.

Anestis, A., A. Lazou, H. O. Pörtner \& B. Michaelidis. 2007. Behavioral, metabolic, and molecular stress responses of marine bivalve Mytilus galloprovincialis during long-term acclimation at increasing ambient temperature. Am. J. Physiol. Regul. Integr. Comp. Physiol. 293:R911-R921.

Brenner, M., D. Fraser, K. Van Nieuwenhove, F. O'Beirn, B. H. Buck, J. Mazurié, G. Thorarinsdottir, P. Dolmer, A. Sanchez-Mata, O. Strand, G. Flimlin, L. Miossec \& P. Kamermans. 2014. Bivalve aquaculture transfers in Atlantic Europe. Part B: environmental impacts of transfer activities. Ocean Coast. Manage. 89:139-146.

Bressan, M., A. Chinellato, M. Munari, V. Matozzo, A. Manci, T. Marceta, L. Finos, I. Moro, P. Pastore, D. Badocco \& M. G. Marin. 2014. Does seawater acidification affect survival, growth and shell integrity in bivalve juveniles? Mar. Environ. Res. 99:136-148.

Bryman, A. 2008. Social research methods, $3^{\text {rd }}$ edition. New York, NY: Oxford University Press. 748 pp.
Callaway, R., A. P. Shinn, S. E. Grenfell, J. E. Bron, G. Burnell, E. J. Cook, M. Crumlish, S. Culloty, K. Davidson, R. P. Ellis, K. J. Flynn, C. Fox, D. M. Green, G. C. Hays, A. D. Hughes, E. Johnston, C. D. Lowe, I. Lupatsch, S. Malham, A. F. Mendzil, T. D. Nickell, T. Pickerell, A. F. Rowley, M. S. Stanley, D. R. Tocher, J. F. Turnbull, G. Webb, E. Wootton \& R. J. Shields. 2012. Review of climate change impacts on marine aquaculture in the UK and Ireland. Aquat. Conserv. 22:389-421.

Candan, A., S. Karataş, H. Küçüktaş \& I. Okumuş, editors. 2007. Marine aquaculture in Turkey. Istanbul, Turkey: Turkish Marine Research Foundation. $134 \mathrm{pp}$.

Campbell, B. \& D. Pauly. 2013. Mariculture: a global analysis of production trends since 1950. Mar. Policy 39:94-100.

CIESM. 2008. Economic valuation of natural coastal and marine ecosystems. CIESM workshop monographs no. 37 [F Briand editor]. CIESM, 16 bd de Suisse, MC-98000, Monaco. 112 pp.

Cochrane, K., C. De Young, D. Soto \& T. Bahri, editors. 2009. Climate change implications for fisheries and aquaculture: overview of current scientific knowledge. FAO Fisheries and Aquaculture Technical Paper. No. 530. Rome: FAO. 212 pp. 
Coma, R., M. Ribes, E. Serrano, E. Jiménez, J. Salat \& J. Pascual. 2009. Global warming-enhanced stratification and mass mortality events in the Mediterranean. Proc. Natl. Acad. Sci. USA 106:6176-6181.

Comité National de la Conchyliculture. 2013. List of shellfish farming production areas with its associated database. EUROSHELL FP7 EU Project. Accessed October 2014. Available at: http://www. euroshell-fp7.eu/Project.

Cooley, S. R. \& S. C. Doney. 2009. Anticipating ocean acidification's economic consequences for commercial fisheries. Environ. Res. Lett. 4:8.

CRCM. 2014. Les zones de production de coquillages Mediterraneens. Accessed October 2014. Available at: http://www.srcm.fr.

Danioux, C., X. Bompais, P. Paquotte \& C. Loste. 2000. Offshore mollusc production in the Mediterranean basin. In: Muir J. \& B. Basurco B, editors. Mediterranean offshore mariculture. Zaragoza: CIHEAM. Options Méditerranéennes: Série B. Etudes et Recherches 30:115-140

Deason, G., E. Seekamp \& C. Barbieri. 2014. Perceived impacts of climate change, coastal development and policy on oyster harvesting in the Southeastern United States. Mar. Policy 50:142-150.

Duarte C., J. M. Navarro, K. Acuna, R. Torres, P. H. Manriquez, M. A. Lardies, C. A. Vargas, N. A. Lagos \& V. Aguilera. 2014. Combined effects of temperature and ocean acidification on the juvenile individuals of the mussel Mytilus chilensis. J. Sea Res. 85:308S314.

Edwards, M. \& A. J. Richardson. 2004. Impact of climate change on marine pelagic phenology and trophic mismatch. Nature 430:881-884.

EU. 2014. List of EU countries, candidates, and potential candidates. Accessed October 2014. Available at: http://europa.eu/about-eu/ countries/index_en.htm.

European Commission. 2009. Fish/2006/09. Assessment of the status, development and diversification of fisheries-dependent communitiesAmvrakikos Gulf case study report. MRAG Consortium: socioeconomic dependency case study reports. 63 pp. Available at: http://ec. europa.eu/fisheries/documentation/studies/regional_social_economic_ impacts/amvrakikos_en.pdf.

EUROSTAT. 2011. Regions in the European Union. Nomenclature of territorial units for statistics. NUTS 2010/EU-27. 2011 edition. Luxembourg: Publications Office of the European Union. 143 pp.

FAO. 2010. Aquaculture production 1950-2012 FishStat Plus. Accessed May and October 2014. Available at: http://www.fao. org/fishery/statistics/software/fishstat/en.

GADM. 2014. Database of global administrative areas. Accessed July 2014. Available at: http://www.gadm.org.

Gazeau, F., C. Quiblier, J. M. Jansen, J.-P. Gattuso, J. J. Middelburg \& C. H. R. Heip. 2007. Impact of elevated $\mathrm{CO}_{2}$ on shellfish calcification. Geophys. Res. Lett. 34:1-5.

Gazeau, F., L. M. Parker, S. Comeau, J.-P. Gattuso, W. A. O'Connor, S. Martin, H.-O. Pörtner \& P. M. Ross. 2013. Impacts of ocean acidification on marine shelled molluscs. Mar. Biol. 160:2207-2245.

Gazeau, F., S. Alliouane, C. Bock, L. Bramanti, M. Gentille, T. Hirse, M. López Correa, H.-O. Pörtner \& P. Ziveri. 2014. Impact of ocean acidification and warming on the Mediterranean mussel (Mytilus galloprovincialis). Front. Mar. Sci. doi: 10.3389/ fmars.2014.00062.

Gervasoni E., A. Perignon, E. Sourisseau, H. Rey-Valette, F. Lagarde, J. Perez, E. Yimam \& N. Feldman. 2011. Monographie: La conchyliculture en Méditerranée. Cepralmar, le CRCM, le Lameta et l'Ifremer. Région Languedoc-Roussillon. 29 pp.

Gualdi, S., S. Somot, L. Li, V. Artale, M. Adani, A. Bellucci, A. Braun, S. Calmanti, A. Carillo, A. Dell'Aquila, M. Déqué, C. Dubois, A. Elizalde, A. Harzallah, D. Jacob, B. L'Hévéder, W. May, P. Oddo, P. Ruti, A. Sanna, G. Sannino, E. Scoccimarro, F. Sevault \& A. Navarra. 2013. The CIRCE simulations: regional climate change projections with realistic representation of the Mediterranean Sea. Bull. Am. Meteorol. Soc. 94:65-81.

Giuffrè, A., R. Mamone, G. Albano \& F. Saracino. 2012. Censimento regionale dei mitilicoltori pugliesi. Centro Ittico Tarantino Progetto
"Valorizzazione delle mitilicolture pugliesi" finanziato dal FEP 2007-2013 Mis. 3.4., pp. 1-6.

Harvell, C. D., C. E. Mitchell, J. R. Ward, S. Altizer, A. P. Dobson, R. S. Ostfeld \& M. D. Samuel. 2002. Climate warming and disease risks for terrestrial and marine biota. Science 296:2158-2162.

Hiebenthal, C., E. E. R. Philipp, A. Eisenhauer \& M. Wahl. 2013. Effects of seawater $p \mathrm{CO}_{2}$ and temperature on shell growth, shell stability, condition and cellular stress of Western Baltic Sea Mytilus edulis (L.) and Arctica islandica (L.). Mar. Biol. 160:2073-2087.

Hilmi, N., D. Allemand, M. Cinar, S. Cooley, J. M. Hall-Spencer, G. Haraldsson, C. Hattam, R. A. Jeffree, J. C. Orr, K. Rehdanz, S. Reynaud, A. Safa \& S. Dupont. 2014. Exposure of Mediterranean countries to ocean acidification. Water 6:1719-1744.

Intergovernmental Panel on Climate Change (IPCC). 2007. Climate change 2007: the physical science basis. Contribution of working group I to the fourth assessment report of the Intergovernmental Panel on Climate Change. Cambridge, United Kingdom and New York, NY: Cambridge University Press. 996 pp.

Intergovernmental Panel on Climate Change (IPCC). 2013. Climate change 2013: the physical science basis. Contribution of Working Group I to the Fifth Assessment Report of the Intergovernmental Panel on Climate Change. Stocker, T. F., D. Qin, G.-K. Plattner, M. Tignor, S. K. Allen, J. Boschung, A. Nauels, Y. Xia, V. Bex and P. M. Midgley, editors. Cambridge, United Kingdom and New York, NY: Cambridge University Press. 1535 pp.

Khatiwala, S., F. Primeau \& T. Hall. 2009. Reconstruction of the history of anthropogenic $\mathrm{CO} 2$ concentrations in the ocean. Nature 462:346-349.

Kroeker, K. J., R. L. Kordas, R. N. Crim, I. E. Hendriks, L. Ramajo, G. S. Singh, C. M. Duarte \& J.-P. Gattuso. 2013. Impacts of ocean acidification on marine organisms: quantifying sensitivities and interaction with warming. Glob. Change Biol. 19:1884-1896.

Kroeker, K. J., B. Gaylord, T. M. Hill, J. D. Hosfelt, S. H. Miller \& E. Sanford. 2014. The role of temperature in determining species' vulnerability to ocean acidification: a case study using Mytilus galloprovincialis. PLoS One 9:e100353.

Lannig, G., S. Eilers, H. O. Portner, I. M. Sokolova \& C. Bock. 2010. Impact of ocean acidification on energy metabolism of oyster, Crassostrea gigas-changes in metabolic pathways and thermal response. Mar. Drugs 8:2318-2339.

Le Quéré, C., G. P. Peters, R. J. Andres, R. M. Andrew, T. A. Boden, P. Ciais, P. Friedlingstein, R. A. Houghton, G. Marland, R. Moriarty, S. Sitch, P. Tans, A. Arneth, A. Arvanitis, D. C. E. Bakker, L. Bopp, J. G. Canadell, L. P. Chini, S. C. Doney, A. Harper, I. Harris, J. I. House, A. K. Jain, S. D. Jones, E. Kato, R. F. Keeling, K. Klein Goldewijk, A. Körtzinger, C. Koven, N. Lefévre, F. Maignan, A. Omar, T. Ono, G.-H. Park, B. Pfeil, B. Poulter, M. R. Raupach, P. Regnier, C. Rödenbeck, S. Saito, J. Schwinger, J. Segschneider, B. D. Stocker, T. Takahashi, B. Tilbrook, S. van Heuven, N. Viovy, R. Wanninkhof, A. Wiltshire \& S. Zaehle. 2014. Global carbon budget 2013. Earth Syst. Sci. Data 6:235-263.

Lima, F. P. \& D. S. Wethey. 2012. Three decades of high-resolution coastal sea surface temperatures reveal more than warming. Nat. Commun. 3:704.

Lök, A. 2009. Government promotes shellfish aquaculture in Turkey. Global Environmental Alliance. Accessed October 2014. Available at: http://pdf.gaalliance.org/pdf/GAA-Lok-Mar09.pdf.

Lovato, T., M. Vichi \& P. Oddo. 2013. High-resolution simulations of Mediterranean Sea physical oceanography under current and scenario climate conditions: model description, assessment and scenario analysis, CMCC Research Papers, RP0207.

Macias, D., E. Garcia-Gorriz \& A. Stips. 2013. Understanding the causes of recent warming of Mediterranean waters. How much could be attributed to climate change? PLoS One 8:e81591.

Magrama. 2010. Producción de acuicultura. Accessed May 2014. Available at: http://www.magrama.gob.es/es/pesca/temas/acuicultura/ produccion-de-acuicultura/default.aspx. 
Mackenzie, C. L., S. A. Lynch, S. C. Culloty \& S. K. Malham. 2014. Future oceanic warming and acidification alter immune response and disease status in a commercial shellfish species, Mytilus edulis L. PLoS One 9:e99712.

Meier, S., L. Beaufort, S. Heussner \& P. Ziveri. 2014. Thinning coccoliths due to ocean acidification and warming in the Mediterranean Sea. Biogeosciences 11:2857-2869.

Melaku Canu, D. \& C. Solidoro. 2013. Socio-economic analysis and stakeholder involvement: mussel-farming in the Gulf of Trieste. Mar. Policy 43:55-62.

Michaelidis, B., C. Ouzounis, A. Paleras \& H. O. Pörtner. 2005. Effects of long-term moderate hypercapnia on acid-base balance and growth rate in marine mussels Mytilus galloprovincialis. Mar. Ecol. Prog. Ser. 293:109-118.

Ministry of Rural Development and Food, Hellenic Republic. 2014. Information page on aquaculture production businesses. Accessed October 2014. Available at: http://www.minagric.gr/index.php/en/ farmer-menu-2/livestock-menu/482-molluscs-fishery-cat.

Moore, C. 2011. Welfare impacts of ocean acidification: an integrated assessment model of the US mollusk fishery. US Environmental Protection Agency, National Center for Environmental Economics. Working paper series 2011; 11-06. 31 pp.

Muehlbauer, F., D. Fraser, M. Brenner, K. Van Nieuwenhove, B. H. Buck, O. Strand, J. Mazurié, G. Thorarinsdottir, P. Dolmer, F. O’Beirn, A. Sanchez-Mata, G. Flimlin \& P. Kamermans. 2014. Bivalve aquaculture transfers in Atlantic Europe. Part A: transfer activities and legal framework. Ocean Coast. Manage. 89:127-138.

Narita, D., K. Rehdanz \& R. S. J. Tol. 2011. Economic costs of ocean acidification: a look into the impacts on shellfish production. ESRI Working Paper; 391.25 pp.

Noone, K., R. Sumaila \& R. J. Díaz, editors. 2013. Valuing the oceandraft executive summary. Stockholm Environment Institute.

O'Donnell, M., M. N. George \& E. Carrington. 2013. Mussel byssus attachment weakened by ocean acidification. Nat. Clim. Chang. 3:587-590.

Orr, J. 2011. Recent and future changes in ocean carbonate chemistry. In: Gattuso, J. \& L. Hansson, editors. Ocean acidification. New York, NY: Oxford University Press. pp. 41-66.

Pörtner, H. O., M. Langenbuch \& A. Reipschlager. 2004. Biological impact of elevated ocean $\mathrm{CO}_{2}$ concentrations: lessons from animal physiology and earth history. J. Oceanogr. 60:705-718.

Range, P., M. A. Chicharo, R. Ben-Hamadou, D. Pilo, M. J. FernandezReiriz, U. Labarta, M. G. Marin, M. Bressan, V. Matozzo, A. Chinellato, M. Munari, N. T. El Menif, M. Dellali \& L. Chicharo. 2014. Impacts of $\mathrm{CO}_{2}$-induced seawater acidification on coastal Mediterranean bivalves and interactions with other climatic stressors. Reg. Environ. Change 14:S19-S30.

Regione Marche. 2008. Assessorato alla pesca. Le concessioni demaniali maritime nelle Marche. Accessed October 2014. Available at:
http://www.pesca.marche.it/web/PROGRAMMAZ/Pubblicazi/IlMare-Produce.pdf.

Rodolfo-Metalpa, R., F. Houlbreque, E. Tambutte, F. Boisson, C. Baggini, F. P. Patti, R. Jeffree, M. Fine, A. Foggo, J. P. Gattuso \& J. M. Hall-Spencer. 2011. Coral and mollusc resistance to ocean acidification adversely affected by warming. Nat. Clim. Chang. $1: 308-312$.

Rosa, R., M. Marques \& M. L. Nunes. 2012. Impact of climate change in Mediterranean aquaculture. Rev. Aquaculture 4:163-177.

Sabine, C. L., R. A. Feely, N. Gruber, R. M. Key, K. Lee, J. L. Bullister, C. S. Wong, D. W. R. Wallace, B. Tilbrook, F. J. Millero, T.-H. Peng, A. Kozyr, T. Ono \& A. F. Rios. 2004. The oceanic sink for anthropogenic $\mathrm{CO}_{2}$. Science 305:367-371.

Stachowicz, J. J., J. R. Terwin, R. B. Whitlatch \& R. W. Osman. 2002. Linking climate change and biological invasions: ocean warming facilitates nonindigenous species invasions. Proc. Natl. Acad. Sci. USA 99:15497-15500.

The Royal Society. 2005. Ocean acidification due to increasing atmospheric carbon dioxide. Policy Document 12/05. Cardiff, UK: The Clyvedon Press Ltd.

Theodorou, J. A., J. Viaene, P. Sorgeloos \& I. Tzovenis. 2011. Production and marketing trends of the cultured Mediterranean mussel Mytilus galloprovincialis Lamarck 1819, in Greece. J. Shellfish Res. 30:859-874.

United Nations Demographic and Social Statistics. Accessed February 2012. Available at: http://unstats.un.org/.

UNEP. 2009. State of the environment and development in the Mediterranean. UNEP/MAP -Blue Plan, Athens. 200 pp.

Vukovic, B. 2006. Montenegro's fisheries development strategy and capacity building for implementation of the EU common fisheries policy. Podgorica.

Washington State Blue Ribbon Panel on Ocean Acidification. 2012. Ocean acidification: from knowledge to action, Washington state's strategic response. Adelsman H. \& L. Whitely Binder, editors. Publication no. 12-01-015. Olympia, WA: Washington Department of Ecology.

World Resource Institute (WRI). 2009. Accessed February 2013. Available at: http://www.wri.org.

World Resource Institute (WRI). 2014. Interactive map of eutrophication \& hypoxia. Accessed October 2014. Available at: http://www. wri.org/media/maps/eutrophication/fullscreen.html.

Ziveri P. 2012. Research turns to acidification and warming in the Mediterranean Sea, IMBER (Integrated Marine Biogeochemistry and Ecosystem Research), Newsletter Issue no. 20.

Ziveri P. \& MedSeA Consortium. 2014. Mediterranean Sea acidification in a changing climate: the European MedSeA project, Open Science Conference, Future Oceans, IMBER, Bergen, Norway, June 23-27, 2014. 
APPENDIX

TABLE A1.

Classification of coastal regions in different countries.

\begin{tabular}{|c|c|c|}
\hline \multirow[b]{2}{*}{ Country } & \multicolumn{2}{|r|}{ Mediterranean coastal regions } \\
\hline & Regional units & Names \\
\hline Albania & 1 (the whole country) & Albania \\
\hline Algeria & 15 of 48 wilayas (provinces) & $\begin{array}{l}\text { Ain Tamouchent, Alger, Annaba, Béjaia, Boumerdès, Chlef, El Tarf, Jijel, Mascara, } \\
\text { Mostaganem, Oran, Skikda, Tipaza, Tizi Ouzou, Tlemcen }\end{array}$ \\
\hline Bosnia-Herzegovina & 1 of 3 districts & Federation of Bosnia-Herzegovina \\
\hline Croatia & 1 of 2 regions & Adriatic Region of Croatia \\
\hline Cyprus & 1 (the whole country) & Cyprus \\
\hline Egypt & 8 of 26 governorates & $\begin{array}{l}\text { Ad Daqahliyah, Al Buhayrah, Al Iskandariyah, Bur Sàid, Dumyat, Kafr ash Shaykh, } \\
\text { Matruh, Shamal Sina' }\end{array}$ \\
\hline France & 3 of 22 regions & Corse, Languedoc-Roussillon, Provence-Alpes-Cote d'Azur \\
\hline Greece & 12 of 13 regions & $\begin{array}{l}\text { Anatoliki Makedonia, Thraki, Attiki, Dytiki Ellada, Ionioi Nisoi, Ipeiros, Kentriki } \\
\text { Makedonia, Kriti, Notio Aigaio, Peloponnisos, Stereá Elláda, Thessalia, Voreio } \\
\text { Aigaio }\end{array}$ \\
\hline Israel & 5 of 6 districts & HaDarom, Haifa, HaMerkaz, HaZafon, Tel Aviv \\
\hline Italy & 16 of 20 regions & $\begin{array}{l}\text { Abruzzo, Apulia, Basicalata, Calabria, Campania, Emilia-Romagna, Fiuli-Venezia- } \\
\text { Giulia, Lazio, Liguria, Marche, Molise, Sardegna, Sicilia, Toscana, Umbria, Veneto }\end{array}$ \\
\hline Lebanon & 4 of 6 governorates & Beirut, Mount Lebanon, North Lebanon, South Lebanon \\
\hline Libya & 16 of 32 governorates & $\begin{array}{l}\text { Ajdabiya, Al Butnan, Al Hizam Al Akhdar, Al Jabal al Akhdar, Al Marj, Al Marqab, } \\
\text { Al Qubbah, Na Nuqat al Khams, Az Zawiyah, Benghasi, Darnah, Misratah, } \\
\text { Sabratah Surman, Surt, Tajura'wa na Nawahi al Arba, Tarabulus }\end{array}$ \\
\hline Malta & 1 (the whole country) & Malta \\
\hline Monaco & 1 (the whole country) & Monaco \\
\hline Montenegro & 1 (the whole country) & Montenegro \\
\hline Morocco & 3 of 15 regions & Tanger-Tétouan, Taza-Al Hoceima-Taounate, Oriental \\
\hline Palestinian territories & 1 (the whole country) & Palestinian territories \\
\hline Slovenia & 1 of 2 regions & Western Slovenia \\
\hline Spain & $5 / 18$ autonomous communities & Andalusia, Balearic Islands, Catalonia, Murcia, Valencia \\
\hline Syria & 2 of 14 governorates & Lattakia, Tartus \\
\hline Tunisia & 13 of 24 governorates & $\begin{array}{l}\text { Ariana, Béja, Ben Arous, Bizerte, Gabès, Jendouba, Mahdia, Médenine, Monastir, } \\
\text { Nabeul, Sfax, Sousse, Tunis }\end{array}$ \\
\hline Turkey & 10 of 26 regions & Istambul, Tekirdag, Balikesir, Izmir, Aydin, Bursa, Kocaeli, Antalya, Adana, Hatay \\
\hline
\end{tabular}

Sources: EUROSTAT (2011), GADM (2014).

Libya has currently 22 Governorates. In this study GIS files are adapted to an older configuration, notably 32 Governorates. 
Effect of Environmental Stress on Mediterranean Aquaculture

TABLE A2.

Aquaculture production in Mediterranean regions (2010).

\begin{tabular}{|c|c|c|c|c|}
\hline Regions & Country & $\begin{array}{c}\text { Mollusc } \\
\text { production (tonnes) }\end{array}$ & $\begin{array}{c}\text { Mariculture } \\
\text { production (tonnes) } \dagger\end{array}$ & $\begin{array}{c}\text { Molluses/total } \\
\text { aquaculture production (\%) }\end{array}$ \\
\hline Emilia Romagna & Italy & $35,556.2^{*}$ & $35,667.2$ & 99.7 \\
\hline Veneto & Italy & $28,622.7 *$ & $30,436.7$ & 94.04 \\
\hline Kentriki Makedonia & Greece & $21,068 \dagger$ & $27,068 \S \S$ & 77.8 \\
\hline Languedoc-Roussillon & France & $15,045 \ddagger$ & 15,830 & 95.04 \\
\hline Puglia & Italy & $12,800.4 *$ & $16,326.4$ & 78.4 \\
\hline Sardgena & Italy & $5,192.6^{*}$ & $8,151.6$ & 63.7 \\
\hline Catalonia & Spain & $3,878 \S$ & 6,737 & 57.6 \\
\hline Marche & Italy & $3,507.1 *$ & $3,510.1$ & 99.9 \\
\hline Friuli-Venezia Giulia & Italy & $3,333.2 *$ & $4,337.2$ & 76.9 \\
\hline Provence-Alpes-Cote d'Azur & France & $3,300 \div$ & 5,364 & 61.5 \\
\hline Molise & Italy & $2,750^{*}$ & 3,101 & 88.7 \\
\hline Campania & Italy & $2,419.6^{*}$ & $2,686.6$ & 90.1 \\
\hline Adriatic region of Croatia & Croatia & 2,1009 & 11,300 & 18.6 \\
\hline Liguria & Italy & $1,853.8^{*}$ & $2,116.8$ & 87.6 \\
\hline Sterea Ellada & Greece & $1,500 \|$ & 21,275 & 7.1 \\
\hline Albania & Albania & $1,410+9$ & 2,127 & 66.3 \\
\hline Sicily & Italy & $1,305^{*}$ & 4,715 & 27.7 \\
\hline Corse & France & $1,300 \ddagger$ & 2,837 & 45.8 \\
\hline Anatoliki Makedonia, Thraki & Greece & $1,200 \dagger$ & 1,581 & 75.9 \\
\hline Abruzzo & Italy & $1,181.8^{*}$ & $1,321.8$ & 89.4 \\
\hline Andalusia & Spain & $791.1 \S$ & $8,466.1$ & 9.3 \\
\hline Lazio & Italy & $698^{*}$ & 1,760 & 39.7 \\
\hline Balikesir & Turkey & $340 \dagger$ & 1,574 & 21.6 \\
\hline Valencia & Spain & $204.4 \S$ & $11,378.4$ & 1.8 \\
\hline Montenegro & Montenegro & $200 \dagger 9$ & 329 & 60.8 \\
\hline Ipeiros & Greece & $200 * *$ & 4,514 & 2.2 \\
\hline Bizerte & Tunisia & $167 \dagger$ & 167 & 100 \\
\hline Balearic Islands & Spain & $150 \S$ & 150 & 100 \\
\hline Calabria & Italy & $80^{*}$ & 246 & 32.5 \\
\hline Southern Slovenia & Slovenia & $77.7 \dagger \dagger$ & 118.7 & 65.5 \\
\hline Federation of Bosnia-Herzegovina & Bosnia-Herzegovina & $70 \div 9$ & 260 & 26.9 \\
\hline Voreio Aigaio & Greece & $53 \dagger$ & 5,992 & 0.9 \\
\hline Attiki & Greece & $48 \dagger$ & 3,576 & 1.3 \\
\hline Nador & Morocco & $12 \dagger \uparrow$ & 49 & 24.5 \\
\hline El-Tarf & Algeria & $4+9$ & 128 & 3.1 \\
\hline Izmir & Turkey & națț & na & na \\
\hline Adana & Turkey & națț & na & na \\
\hline Total & - & $152,418.25$ & $245,197.3$ & 62.2 \\
\hline
\end{tabular}

This table only includes Mediterranean coastal regions that produce molluscs. Case study regions are marked in bold. Data inaccuracies might be expected for some regions as different sources reported slightly different data. Data for the total mariculture production were adjusted for the countries which did not had Campbell and Pauly (2013) as a reference for data on mollusc production.

* Personal information provided by the Associazione Mediterranea Acquacoltori (AMA).

$\dagger$ Campbell and Pauly (2013).

† CEPRALMAR (2011).

$\S$ Magrama (2010).

ฯ FAO (2010).

|| Estimation based on Theodorou et al. (2011).

** Estimation based on European Commission (2009).

$\dagger \dagger$ Personal information provided by the Slovenian Hunting and Fisheries Division - Ministry of Agriculture and the Environment.

ț Data were not available for the regions of Izmir and Adana in Turkey despite Candan et al. (2007) and Lök (2009) indicating the existence of mollusc aquaculture farms in these regions.

$\S \S$ Personal information provided by the Decentralized Peripheral Administration of Kentriki Makedonia, Thraki. The estimate was obtained using the maximum production capacity of the licensed fish farms of this area in 2013. 
BOX A1.

Informative text about environmental pressures used in the questionnaire.

Gradual increase in sea water temperature as a result of climate change

During the last $200 \mathrm{y}$, as a consequence of human activities, the increase in the emissions of greenhouse gas such as $\mathrm{CO}_{2}$ has led to a higher mean global temperature of the atmosphere. During this period, $\sim 80 \%$ of the heat added to the climate system was absorbed by the ocean, which in turn is resulting in a gradual increase of the SST. Associated effects include changes at the physiological level of marine organisms and possible shifts on their geographical distribution. Socioeconomic consequences may occur through the decline of the commercial exploitation of seafood species in some regions, which affects human nutrition and livelihoods associated with fisheries and aquaculture (Noone et al. 2013).

Summer heat waves leading to abrupt increases of sea water temperature

Global warming is expected to produce more extreme events such as severe heat waves, floods, and droughts. Summer heat waves could have important effects on the survival of mollusc populations, leading to potential losses in production and revenues for the aquaculture sector.

Ocean acidification

The ocean is the largest natural reservoirs of carbon and has an estimated capture of $25 \%$ of the $\mathrm{CO}_{2}$ emitted by human activities. This absorption of $\mathrm{CO}_{2}$ by the ocean leads to increased acidity levels (decreased $\mathrm{pH}$ ). Although the seawater will remain basic, this $\mathrm{pH}$ decrease will lead to profound changes in the ocean chemistry. Among those changes, carbonate ions, the elements used by many marine species to produce calcareous structures (for instance, mollusc shells) will become significantly lower. Ocean acidification can thus produce effects in the physiology of marine organisms, and lead to direct or indirect negative effects on marine food webs. Important economic sectors, such as fisheries, aquaculture, and tourism, are considered as potentially vulnerable sectors to ocean acidification (IPCC 2007, Sabine et al. 2004, Khatiwala et al. 2009).

Sea level rise

The increase of global temperatures is very likely to raise the sea level through the expansion of ocean water and melting of major ice sheets. Projections by 2100 in the Mediterranean indicate a potential sea level rise of $35 \mathrm{~cm}$. Impacts include floods of coastal land, saltwater intrusion that may affect areas such as lakes and reservoirs, increased erosion and habitat destruction (Rosa et al. 2012, UNEP 2009).

Marine pollution

The Mediterranean Sea connects three continents, and is surrounded by 22 territories, reaching a total population close to the threshold of 500 million inhabitants. The larger number of people living in coastal zones, and the associated intense economic activity, leads to important environmental pressures for the Mediterranean Sea. Marine pollution through toxic chemicals, solid waste, sewage discharge, oils spills, and discarded fishing nets, represents a serious threat to biodiversity, and water quality, with special incidence on estuarine and coastal habitats. Polluted areas may complicate the implementation of certain practices such as aquaculture, and recreational activities (Noone et al. 2013, United Nations Demographic and Social Statistics 2012).

Mollusc diseases

Several diseases affect mollusc species produced in the Mediterranean region (e.g., bonamiosis and mytilicolosis). The prevention and eradication of mollusc diseases are of major concern for the aquaculture sector; however, an appropriate use of prophylactic and treatment measures is essential. In some cases the use of chemicals may trigger toxicity, resistance to diseases in certain species, and produce residues. These aspects can become a matter of public health, and environmental degradation (Rosa et al. 2012).

Eutrophication

This pressure is described as the ecosystem response to the over enrichment of water by nutrient flows, primarily delivered to the marine ecosystem from land-based activities such as agricultural practices, industrial activities and population growth. Symptoms of eutrophication include the depletion of oxygen, also known as hypoxia, HAB and drastic decrease in biodiversity. Impacts range from the loss of subaquatic vegetation, change in species composition, and the formation of oxygen-depleted waters, also known as 'dead zones' (World Resource Institute [WRI] 2009).

Harmful algal blooms

Rapid increases in the population of harmful algal species may occur in marine environments. Increased temperatures associated with eutrophication can enhance the occurrence of these toxic tides and lead to negative impacts on aquaculture (e.g., in the farming of filter feeders). Risks for human health reside in the contamination of seafood, and may result in some illness such as diarrheic shellfish poisoning DSP and paralytic shellfish poisoning. Enhanced HAB would adversely affect tourism as well as regional fisheries and aquaculture production (Rosa et al. 2012, CIESM 2008).

Invasive species

The intrusion of nonendemic species in marine habitats may accelerate the decline of native species, leading to population losses and extinctions at the local level. Biological invasions are considered one of biggest causes of biodiversity loss, and are recognized as a threat to the economy and also human health (UNEP 2009). 